\title{
Pengaruh Kemampuan Numerik dan Algoritma terhadap Kemampuan Pemrograman dalam Pilihan Tema Skripsi
}

\author{
Muhammad Haviz Irfani \\ Sistem Informasi, Sains dan Teknologi, UIN Raden Fatah, \\ Jalan Prof. K. H. Zainal Abidin Fikri Palembang \\ e-mail: haviz.irfani@gmail.com
}

(received: 9 Oktober 2020, revised: 8 Desember 2020, accepted: 19 Desember 2020)

\begin{abstract}
Abstrak
Keberhasilan mahasiswa dalam lingkungan program studi Sistem Informasi UIN Raden Fatah Palembang menyelesaikan tugas akhir atau skripsi sangat ditentukan oleh tema skripsi yang dipilih. Mahasiswa cenderung untuk menghindari penelitian dalam konteks pengembangan sistem (membuat aplikasi/ coding) sehingga mempengaruhi mahasiswa lainnya untuk melakukan hal yang sama setiap semesternya. Kenyataannya kemampuan membuat kode bahasa pemrograman atau melakukan penelitian analisis (tidak membuat aplikasi) keduanya berkontribusi dalam membuat keputusan menentukan tema skripsi. Penelitian ini bertujuan untuk mengetahui seberapa besar pengaruh kemampuan numerik dan logika, dan algoritma terhadap kemampuan membuat kode bahasa pemrograman untuk hasil pilihan tema skripsi mahasiswa program studi Sistem Informasi Universitas Islam Negeri Raden Fatah Palembang. Penting diteliti faktor kemampuan numerik dan logika, kemampuan analisis data, kemampuan algoritma dan pemrograman mempengaruhi kemampuan mahasiswa membuat kode bahasa pemrograman, serta secara simultan pengaruhnya terhadap hasil pilihan tema skripsi. Data hasil studi mahasiswa diolah menggunakan Lisrel 8.80, selain itu uji prasyarat analisis SEM yang digunakan dalam penelitian (berupa uji asumsi kecukupan sampel, uji klasik, dan evaluasi outlier, dan Uji fit model. Mahasiswa Sistem Informasi dalam memilih tema skripsi (membuat kode program) tidak terlalu besar dipengaruhi secara bersama-sama oleh kemampuan numerik dan logika, kemampuan analisis data, kemampuan algoritma dan pemrograman, dan juga kemampuan membuat program.
\end{abstract}

Kata Kunci: algoritma, logika, numerik, statistik, structural equation modeling

\begin{abstract}
The successful of students in the Information System study program of Islamic State University of Raden Fatah Palembang in completing their final project or thesis is largely determined by their thesis theme. Students tend to avoid research in the context of system development (making applications / coding) so as to influence other students to do the same thing every semester. In fact, the ability to code a programming language or conduct analytical research (not to create applications) both contributes to the decision to determine the thesis theme. This study aims to determine how is the influence numerical and logical, data analysis, programming and algorithmic abilities on the ability to code programming languages for the thesis theme choices of students of the Information Systems study program of Islamic State University of Raden Fatah Palembang. It is important to examine the factors of numerical ability, data analysis skills, logical and algorithmic abilities affecting students' ability to code programming languages, and simultaneously these effects on the results of the thesis theme choice. Students final results were processed using Lisrel 8.80, besides the prerequisite tests for SEM (Structural Equation Model) analysis used in this study was in the form of assumptions on sample adequacy test, classic test, and evaluation of outliers, and model fit test. Information Systems students in choosing a thesis theme (making program code) were not highly influenced by numerical and logical abilities, data analysis skills, algorithmic and programming abilities, and also the ability to create programs.
\end{abstract}

Keywords: algorithm, logic, numeric, statistics, structural equation modeling 


\section{Pendahuluan}

Mahasiswa yang menjadi responden berasal dari Program studi Sistem informasi yang berada pada Fakultas Sains dan Teknologi Universitas Islam Negeri Raden Fatah Palembang dipilih dari angkatan Tahun 2013, 2014, dan 2015 yang telah mengambil matakuliah pemrograman sebagai sampel dalam penelitian ini. Sebanyak 226 orang mahasiswa yang telah di yudisium dan jumlah judul skripsi kategori Pemrograman sebesar $67.26 \%$ sisanya $32.74 \%$ ketegori judul skripsi Non Pemrograman menjadi informasi sebagai hasil observasi objek penelitian yang terlihat pada Tabel 1 .

Penelitian "Pengaruh kemampuan metakognitif terhadap prestasi akademik mahasiswa pada mata kuliah pemrograman dasar" memberikan uraian bahwa metakognisi (pengetahuan (knowledge) dan regulasi (regulation) pada suatu aktivitas kognitif seseorang dalam proses belajarnya atau pengetahuan tentang apa yang dipelajari atau bagaimana belajar [1]. Adapun fokus pada kemampuan kognitif mencakup kegiatan mental (otak) atau segala upaya yang menyangkut aktivitas otak, ranah kognitif memiliki enam jenjang atau aspek yaitu pengetahuan/ hafalan/ ingatan (knowledge), Pemahaman (comprehension), Penerapan (application), Analisis (analysis), Sintesis (syntesis), dan Penilaian/ evaluasi (evaluation) [1]. Selain itu juga kemampuan kognitif dijadikan ukuran kecakapan mahasiswa untuk menentukan tema skripsi yang dipilih, dalam penelitian ini ada dua kategori yaitu membuat program (kode program) atau analisis data (tanpa membuat program).

Penelitian oleh Bayu Hermawan Adi Pratama dan Bambang Sujatmiko [2] yaitu analisis pengaruh nilai tes potensi akademik (mengetahui bakat dan kemampuan seseorang) pada evaluasi pemrograman dasar (proses menulis, menguji dan memperbaiki (debug), dan memelihara kode yang membangun sebuah program komputer) terhadap motivasi (hasrat dan keinginan, dorongan dan kebutuhan, harapan dan cita-cita, perhargaan dalam belajar, kegiatan menarik dalam belajar, lingkungan belajar yang kondusif) dan kemampuan pemrograman (kesanggupan atau kecakapan seorang individu dalam menguasai keahlian bidang pemrograman yang terdiri dari bahasa pemrograman dasar, sub-sub pemrograman dasar, dan logika pemrograman) menunjukkan hubungan antara tes potensi akademik dan motivasi belajar dengan tes pemrograman dasar memiliki hubungan yang positif dan signifikan. Dengan kata lain ada pengaruh signifikan antara nilai tes potensi akademik dan motivasi belajar dengan nilai akhir pemrograman dasar terhadap kemampuan pemrograman.

Pemrograman pada dasarnya adalah aplikasi praktis dari salah satu bidang dasar matematika, yaitu aljabar. Oleh karena itu, menguraikan kemampuan yang dibutuhkan untuk melakukan koding (membuat kode bahasa program) adalah kemampuan matematika dasar, kemampuan logika, kemampuan merencanakan dan memahami fungsi perangkat keras dan lunak yang terdapat pada komputer dengan sangat baik.

Hal tersebut menjadi dasar untuk menentukan beberapa mata kuliah yang diperoleh dari buku pedoman kurikulum program studi Sistem Informasi digunakan data nilai akhir studi sebagai data kemampuan numerik dan logika yaitu mata kuliah Matematika, Matematika Diskrit, dan Basis Data.

Adapun analisis merupakan tahap seseorang berfikir secara reaktif dan kritis dengan menggunakan berbagai metode untuk membuktikan penyelesaian pokok permasalahan yang dibahas sebagai penguat dengan mengaitkan data (fakta). Kemampuan analisis data diukur dari nilai akhir studi mata kuliah statistik dan probabilitas, dan rekayasa perangkat lunak. Matakuliah Statistik dan Probabilitas mahasiswa memiliki kemampuan analisis data yang kuat untuk merespon objek penelitian pada tugas akhir/ skripsi, juga mata kuliah rekayasa perangkat lunak berisi metodologi untuk menjawab apa, bagaimana, penerapan, validasi, dan pengujian perangkat lunak yang dibuat. Keduanya memberikan dampak kemampuan analisis data yang kuat bagi mahasiswa semester akhir.

Penelitian Ramdhan F. Suwarman [3] menganalisis tingkat kemampuan pemahaman konsep mahasiswa pada matakuliah pemrograman kompute dengan metode deskriptif kuantitatif memberikan hasil bahwa dari 22 responden mahasiswa pendidikan matematika angkatan pertama yang diukur dengan soal dan dinilai menurut konsep Abraham, secara rata-rata tingkat kemampuan pemahaman konsep mahasiswa adalah sedang sebesar $68,724 \%$, Artinya terdapat kendala dalam kemampuan konsep mahasiswa yang harus diperhatikan. Oleh karena itu, kemampuan algoritma dan pemrogaman diukur menggunakan nilai mata kuliah algoritma dan pemrograman 1 dan 2, dan mata kuliah struktur data. Matakuliah ini juga secara kurikulum seharusnya dapat memberikan dampak besar bagi mahasiswa untuk menyukai membuat kode program dengan jenis bahasa pemrograman apapun. 
Secara umum tema skripsi yang dapat dipilih oleh mahasiswa saat ini yaitu pengembangan sistem informasi (membangun kode program), dan analisis sistem informasi (tanpa membangun kode program). Penelitian ini perlu untuk mengetahui luarannya setelah menyelesaikan studi sampai tahap skripsi bahwa mahasiswa sebagian besar mengangkat tema pengembangan sistem atau sebagian besar melakukan penelitian analisis sistem informasi (tidak melakukan coding program). Dampak yang terjadi mahasiswa terlihat cenderung akhir-akhir ini untuk menghindari penelitian berupa pengembangan sistem (membuat aplikasi atau codding) sehingga mempengaruhi mahasiswa lainnya untuk melakukan hal yang sama setiap semesternya. Selain itu juga dari jumlah keseluruhan mahasiswa yang memilih tema skripsi untuk membuat kode program masih lebih besar dari tema tanpa membuat kode program, tetapi jumlah nilai untuk mata kuliah seperti algoritma dan pemrograman 1, algoritma dan pemrograman 2, dan rekayasa perangkat lunak mahasiswa mendapatkan nilai $\mathrm{C}$ cukup besar jumlahnya.

Oleh karena itu, penting mengetahui pengaruh kemampuan numerik dan logika, analisis data, algoritma dan pemrograman terhadap kemampuan membuat kode bahasa pemrograman, dan juga pengaruh secara simultan kemampuan numerik dan logika, analisis data, algoritma dan pemrograman, dan kemampuan membuat kode bahasa pemrograman terhadap hasil pilihan tema skripsi mahasiswa prodi Sistem Informasi UIN Raden Fatah Palembang.

\section{Tinjauan Literatur}

\subsection{Kesalahan Umum Pemrograman}

Fitria dan Rahmania [4] memberikan hasil penelitiannya pada mahasiswa program studi pendidikan teknologi informasi bahwa terdapat 3 macam kesalahan (error) pada saat deteksi error code yaitu syntax error (kesalahan penulisan kode), runtime error (kesalahan saat program dijalankan), dan logic error (kesalahan logika). Yang paling sulit untuk menyelesaikannya jenis logic error karena kesalahan tersebut tidak memberikan informasi lengkap seperti bentuk error dan letak posisi errornya. Kesalahan lain yang diperoleh mahasiswa kurangnya ketelitian, tidak memahami alur logika program, dan kurang pengetahuan penanganan error yang ditemui secara langsung.

Dalam penelitian oleh Isyatul Mardiyati [5] dengan metode deskriptif pendekatan kuantitatif pada mahasiswa semester 1 bahwa dari 26 orang responden sebanyak 19 orang $(73,08 \%)$ memiliki kemampuan analisis sangat rendah. Semetara kemampuan sintesa rendah sebesar 50\% (13 orang mahasiswa). Kemudian ranah kognitif dalam komponen taksonomi juga termasuk pada proses analisis yang memberikan gambaran kemampuan responden seperti mampu mengklasifikasikan prinsipprinsip, meramalkan kualitas/ kondisi, menghubungkan antar unsur, dan mengenal pola atau mengetengahkan pola hubungan atau sebab akibat.

\subsection{Item Pengukuran Pada Variabel Konstruk}

Ada 3 (tiga) jenis keahlian (proficiency) (terdiri atas: access, manage, integrate, evaluate, dan create) yang saling terkait dalam pengembangan literasi di bidang informatika dan komputer antara lain [6] : (1) Cognitive proficiency: merupakan keahlian mendasar yang diinginkan sehari-hari di sekolah, rumah, dan tempat bekerja. (2) Technical proficiency: merupakan komponen mendasar dari literasi digital. (3) ICT proficiency: merupakan integrasi dan aplikasi antara keahlian koginitf dan keahlian teknis.

Semua indikator diadopsi dari kurikulum KKNI kecuali untuk indikator Y21 dan Y24. Untuk Y23 mata kuliah terkait yaitu metodologi Penelitian, menurut KKNI keterkaitan terhadap ranah topik pada domain bidang ilmu komputer, dan keterkaitan dalam ranah keilmuan seperti struktur diskrit, ilmu komputasi, bahasa pemrograman, Algoritma dan kompleksitas, rekayasa perangkat lunak, dan lain sebagainya [6]. Untuk indikator minat dan nilai skripsi bukan bagian dari mata kuliah ilmu komputer, melainkan bagian dari penilaian kognitif dan hasil akhir penilaian skripsi bagian dari penilaian teknis. 
Tabel 3. Item Pengukuran dari Konstruk [6]

\begin{tabular}{|l|l|}
\hline \multicolumn{1}{|c|}{ Konstruk } & \multicolumn{1}{c|}{ Indikator Pengukuran } \\
\hline Numerik dan Logika & X11: Nilai akhir Matematika \\
(X1) & X12: Nilai akhir Matematika Diskrit \\
& X13: Nilai akhir Basis Data \\
& X14: Nilai akhir Basis Data Lanjutan \\
\hline Analisis Data (X2) & X21:Nilai akhir Statistik dan Probabilitas \\
& X22: Nilai akhir Praktikum Statistik dan Probabilitas \\
& X23: Nilai akhir Rekayasan Perangkat Lunak \\
& X24: Nilai akhir Praktikum Rekayasan Perangkat Lunak \\
\hline \multirow{4}{*}{ dan } & X31:Nilai akhir Algoritma dan Pemrograman 1 \\
Xeritma & X32:Nilai akhir Praktikum Algoritma dan Pemrograman 1 \\
Pemrograman (X3) & X33:Nilai akhir Algoritma dan Pemrograman 2 \\
& X34:Nilai akhir Praktikum Algoritma dan Pemrograman 2 \\
& X35: Nilai akhir Struktur Data \\
& X36: Nilai akhir Praktikum Struktur Data \\
\hline Kemampuan & Y11: Nilai akhir Pemrograman Web \\
Membuat & Y12: Nilai akhir Praktikum Pemrograman Web \\
Program (Y1) & Y13: Nilai akhir Pemrograman Berorientasi Objek \\
& Y14: Nilai akhir Praktikum Pemrograman Berorientasi Objek \\
\hline Pilihan Tema Skripsi & Y21: Minat/ Motivasi \\
(Y2) & Y23: Metodologi Penelitian \\
& Y24: Nilai Skripsi \\
\hline
\end{tabular}

Faktor Numerik dan Logika.

Numerik atau angka yang bersifat sistem angka, data statistik, atau data lain yang membutuhkan pengelolaan. Kemampuan numerik adalah kemampuan dalam hal hitungan angka-angka untuk mengetahui seberapa baik pemahaman ide-ide dan konsep yang dinyatakan dalam bentuk angka atau bilangan [7]. Selain itu juga ukuran numerik yang digunakan dalam penelitian ini diperoleh dari nilai akhir mata kuliah matematika (kalkulus), dan matematika diskrit.

Logika atau masuk akal yang diperlukan untuk membuat pengukuran diperoleh dari nilai akhir mata kuliah kalkulus, matematika diskrit dan aljabar linier [7], sedangkan logika memiliki nilai kebenaran atas hasil true atau false yang menggunakan penalaran.

Dalam membuat kode program untuk setiap pernyataan atau ekspresi pemrogram selalu dihadapkan dengan pernyataan terstruktur dan logis [1], sehingga menjawab semua permasalahan yang akan diselesaikan.

\section{Faktor Kemampuan Analisis Data}

Analisis merupakan langkah untuk mendapatkan hasil dengan menggunakan berbagai metode atau cara yang sesuai dengan outputnya. Kemampuan analisis data diukur dari beberapa nilai akhir mata kuliah statistik dan probabilitas, dan rekayasa perangkat lunak. Karena tidak cukup memiliki kemampuan numerik dan logika, mahasiswa wajib memiliki kemampuan analisis data. Analisis merupakan tahap seseorang berfikir secara reaktif dan kritis dengan menggunakan berbagai metode untuk membuktikan penyelesaian pokok permasalahan yang dibahas sebagai penguat dengan mengaitkan data (fakta). Dengan matakuliah Statistik dan Probabilitas mahasiswa memiliki kemampuan analisis data yang kuat untuk merespon objek penelitian pada tugas akhir, selain itu rekayasa perangkat lunak juga memiliki metodologi untuk menjawab apa, bagaimana, penerapan, validasi, dan pengujian perangkat lunak yang dibuat, sehingga memberikan dampak kemampuan analisis data dan proses yang kuat bagi mahasiswa semester akhir [8].

\section{Faktor Algoritma dan Pemrograman}

Penelitian Nur Fitria H dan Sri Rahmania U yang berkaitan dengan kemampuan analisis data maka dalam pengkodean (pemrograman) terdapat beberapa hal penting yang harus diperhatikan antara lain pertama kesalahan yang bersifat sistematis, dan yang kedua kurang konsisten [4]. Kesalahan tersebut terjadi disebabkan oleh tingkat penguasaan materi yang kurang pada mahasiswa, atau kesalahan yang bersifat insidental yaitu kesalahan yang bukan merupakan akibat dari rendahnya tingkat pengusaan materi, melainkan oleh penyebab lainnya misalnya kurang cermat dalam membaca 
algoritma dan kode program untuk memahami maksud soal yang diberikan pada saat ujian berlangsung [9].

\section{Faktor Kemampuan Pembuatan Kode Program.}

Beberapa indikator kemampuan mahasiswa [4] dalam pembuatan kode program yaitu (1) Kemampuan dan kesulitan mahasiswa dalam menangani error code program; (2) faktor penyebab kesulitan dan kemampuan yang dialami mahasiswa dari dalam diri mahasiswa; (3) faktor penyebab kesulitan dan kemampuan yang dialami mahasiswa dari lingkungan kampus dan teman kuliah; (4) faktor penyebab kesulitan dan kemampuan yang dialami mahasiswa dari lingkungan keluarga.

\section{Faktor Pemilihan Tema Skripsi.}

Dalam pemilihan tema skripsi, mahasiswa pada umumnya memiliki 3 kemampuan [10] yaitu kognitif, afektif, dan psikomotorik yang dapat digunakan untuk mengelola pengetahuan yang diperolehnya. Kognitif - yang mencakup kegiatan mental (otak) atau segala upaya yang menyangkut aktivitas otak. Ranah kognitif memiliki enam jenjang atau aspek, yaitu: (1). Pengetahuan/hafalan/ingatan (knowledge); (2). Pemahaman (comprehension); (3). Penerapan (application); (4). Analisis (analysis); (5). Sintesis (syntesis); dan (6). Penilaian/penghargaan/evaluasi (evaluation). Afektif - berkaitan dengan sikap dan nilai. Ranah afektif ini mencakup watak perilaku seperti perasaan, minat, sikap, emosi, dan nilai. Beberapa pakar menjelaskan bahwa sikap seseorang dapat diramalkan perubahannya bila seseorang telah memiliki kemampuan kognitifnya tingkat tinggi. Ranah afektif menjadi lebih rinci lagi ke dalam lima jenjang, yaitu: (1) Receiving atau attending ( menerima atua memperhatikan); (2) Responding (menanggapi) mengandung arti "adanya partisipasi aktif"; (3) Valuing (menilai atau menghargai); (4) Organization (mengatur atau mengorganisasikan); (5). Characterization by a value or value complex (karakterisasi dengan suatu nilai atau komplek nilai). Psikomotorik - berkaitan dengan keterampilan (skill) atau kemampuan bertindak setelah seseorang menerima pengalaman belajar tertentu. Psikomotor ini sebenarnya kombinasi berkelanjutan dari hasil belajar kognitif (memahami sesuatu) dan hasil belajar afektif (yang baru tampak dalam bentuk kecenderungan-kecenderungan berperilaku).

Kecenderungan mahasiswa memilih tema skripsi saat ini yang menurutnya telah sesuai dengan kemampuannya karena secara alami mahasiswa tersebut telah memiliki keterampilan kognitif, afektif, dan psikomotor. Oleh karena itu, mahasiswa tersebut dapat menyelesaikan studinya tepat pada waktu yang telah ditentukan.

\subsection{Model Penelitian (Konseptual Penelitian)}

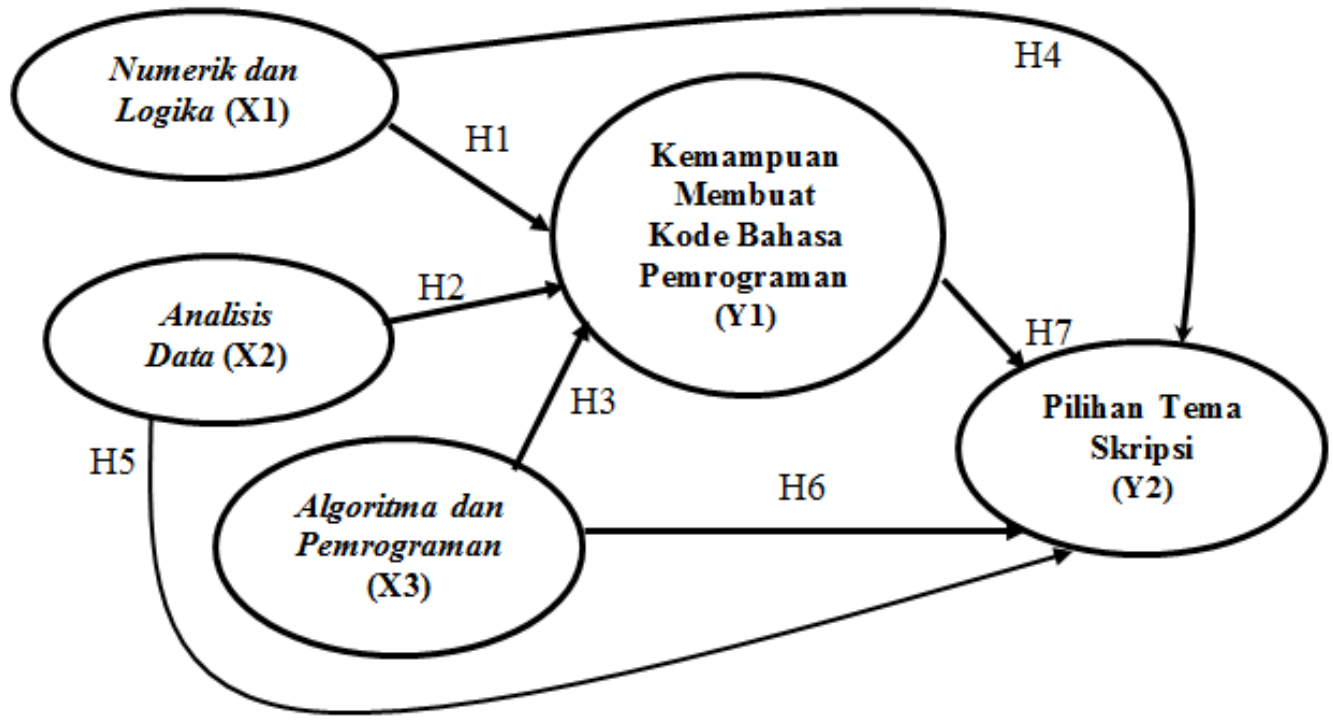

Gambar 1. Model Konsep Penelitian [11] [12]

Hipotesis 1: Hipotesis ini menguji hubungan langsung antara variabel X1 dengan variabel $\mathrm{Y} 1$.

H0: X1 tidak memiliki pengaruh langsung terhadap Y1

H1: X1 memiliki pengaruh langsung terhadap Y1

Hipotesis 2: Hipotesis ini menguji hubungan langsung antara variabel X2 dengan variabel $\mathrm{Y} 1$.

H0: X2 tidak memiliki pengaruh langsung terhadap Y1 
H1: X2 memiliki pengaruh langsung terhadap Y1

Hipotesis 3: Hipotesis ini menguji hubungan langsung antara variabel $\mathrm{X} 3$ dengan variabel $\mathrm{Y} 1$. H0: X3 tidak memiliki pengaruh langsung terhadap Y1

$\mathrm{H} 1$ : X3 memiliki pengaruh langsung terhadap Y1

Hipotesis 4: Hipotesis ini menguji hubungan langsung antara variabel $\mathrm{X} 1$ dengan variabel $\mathrm{Y} 2$.

H0: X1 tidak memiliki pengaruh langsung terhadap Y2

H1: X1 memiliki pengaruh langsung terhadap Y2

Hipotesis 5: Hipotesis ini menguji hubungan langsung antar variabel X2 dengan variabel Y2.

H0: X2 tidak memiliki pengaruh langsung antar variabel Y2

$\mathrm{H} 1$ : X2 memiliki pengaruh langsung antar variabel Y2

Hipotesis 6: Hipotesis ini menguji hubungan langsung antar variabel X3 dengan variabel Y2.

H0: X3 tidak memiliki pengaruh langsung antar variabel Y2

H1: X3 memiliki pengaruh langsung antar variabel Y2

Hipotesis 7: Hipotesis ini menguji hubungan langsung antar variabel Y1 dengan variabel Y2.

H0: Y1 tidak memiliki pengaruh langsung antar variabel Y2

H1: Y1 memiliki pengaruh langsung antar variabel Y2

\section{Metode Penelitian}

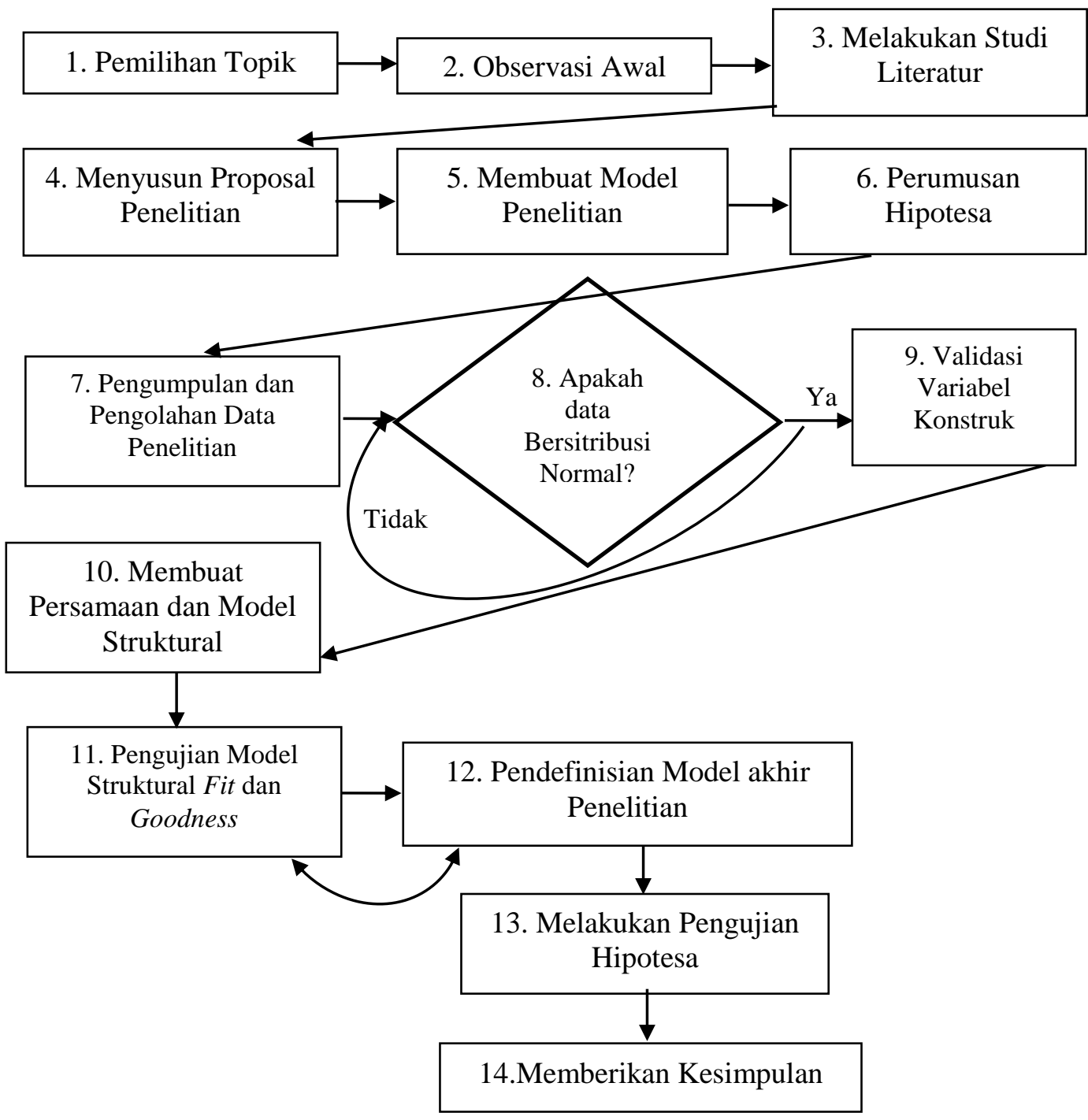

Gambar 2. Tahapan Penelitian 


\subsection{Pengumpulan Data}

Data yang digunakan dalam penelitian bersifat data sekunder dan ordinal yang diberikan oleh pihak PUSTIPD (Pusat Teknologi Informasi danPangkalan Data) UIN Raden Fatah Palembang. Data tersebut berupa nilai hasil belajar matakuliah mahasiswa yang sudah menjadi alumni dengan diperkuat beberapa artikel penelitian terdahulu dan tinjauan buku pedoman akademik prodi Sistem Informasi.

Tabel 1. Ringkasan Total Judul

\begin{tabular}{|l|l|}
\hline \multicolumn{1}{|c|}{ Keterangan } & Jumlah \\
\hline Total Semua Judul Skripsi $=$ & 226 \\
\hline Total Analisis $=$ & 74 \\
\hline Total Non Analisis $=$ & 152 \\
\hline \% Total Analisis $=$ & $\mathbf{3 2 . 7 4}$ \\
\hline \% Total Non Analisis $=$ & $\mathbf{6 7 . 2 6}$ \\
\hline
\end{tabular}

Pilihan tema skripsi berkaitan dengan minat mahasiswa umumnya memiliki 3 kemampuan yaitu kognitif, afektif (sikap), dan psikomotorik (keterampilan) yang digunakan untuk mengelola pengetahuannya. Penelitian "Pengaruh Pembelajaran Generatif Berbasis Strategi Konflik Kognitif Terhadap Kompetensi Mahasiswa Dalam Mata Kuliah Algoritma Dan Pemograman Komputer" memberikan hasil bahwa terdapat pengaruh yang berarti pembelajaran generatif (pemahaman konseptual) berbasis strategi konflik kognitif (rasa keingintahuan (Foster a sense of wonder), keterampilan mengamati (Encourage observation), melakukan analisis (Push for analysis) dan berkomunikasi (Require communication)) terhadap kompetensi mahasiswa dalam Algoritma dan Pemograman Komputer [13] [10].

Berikut persentase yang memperlihatkan kedua kategori dari data kegiatan yudisium ke 5 sampai dengan yudisium ke 10 yang diperoleh dari bagian akademik fakultas setelah dikelompokkan terlihat pada Tabel 2.

Tabel 2. Persentase Yudisium ke 5 sampai ke 10

\begin{tabular}{|c|c|c|}
\hline $\begin{array}{c}\text { Yudisium } \\
\text { ke- }\end{array}$ & \% Analisis & \% Non Analisis \\
\hline 5 & 23.81 & 76.19 \\
\hline 6 & 26.15 & 73.85 \\
\hline 7 & 31.88 & 68.12 \\
\hline 8 & 75.00 & 25.00 \\
\hline 9 & 46.15 & 53.85 \\
\hline 10 & 50.00 & 50.00 \\
\hline
\end{tabular}

\subsection{Pengolahan Data}

Pengolahan data penelitian menggunakan aplikasi microsoft excel, aplikasi SPSS 19.0, dan aplikasi Lisrel 8.80.

\subsection{Pengujian Klasik}

Sebagai syarat mendapatkan persamaan regresi linier maka dilakukan pengujian normalitas data (memastikan berdistribusi normal). Selain itu, validitas variabel konstruk diuji untuk memperlihatkan apakah manifestasi yang dimunculkan dalam model dapat dijelaskan oleh konstruk.

\subsection{Membuat Model Struktural}

Membuat model struktural menggunakan pendekatan metode SEM (Structural Equation Modelling) dan model matematik yang dibuat mengikuti atau berpedoman pada referensi buku literatur yang digunakan. 


\subsection{Pengujian Model}

Analisis SEM dengan uji kebaikan model digunakan seperti uji absolute fit indices, incremental fit indices dan parsimony fit indices. Pendefinisian model akhir yang layak yang diperoleh setelah dipastikan tidak terdapat nilai error covarian yang tinggi dan negatif.

\subsection{Pengujian Hipotesa}

Untuk mendapatkan penerimaan atau penolakan hipotesa nol berdasarkan nilai beta yang muncul pada model. Selanjutnya menarik kesimpulan dan membuat interpretasi hasil penelitian.

\section{Hasil dan Pembahasan}

Recode Data dilakukan dengan merubah nilai A menjadi angka 1, nilai B menjadi angka 2, nilai $\mathrm{C}$ menjadi angka 3, dan nilai D menjadi angka 4. Selain itu untuk tema skipsi Rancangan Program menjadi angka 1, dan Analisis Data menjadi angka 2 (Gambar 3 dan Gambar 4).

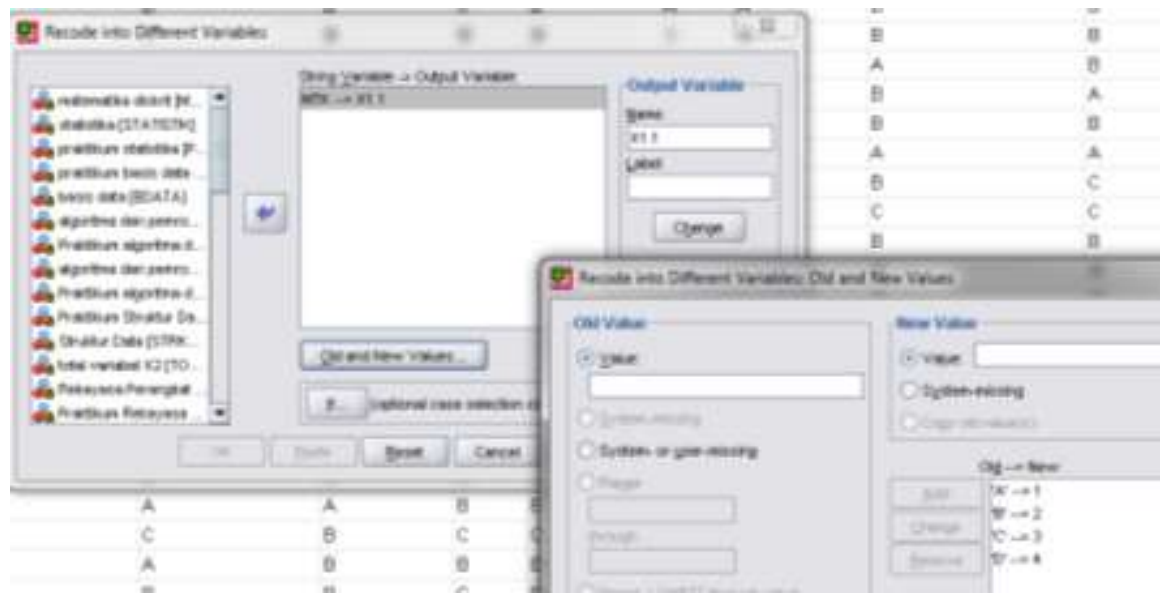

Gambar 3. Recode Data dengan Aplikasi SPSS [14]

\begin{tabular}{|c|c|c|c|c|c|c|c|c|c|c|c|c|c|c|c|c|c|c|c|c|c|c|c|}
\hline & $x 11$ & 01 & 193 & $x 20$ & 12 & $x 2$ & Dos & 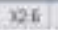 & 821 & 02 & (a) & 04 & os: & xat & $\mathrm{nI}$ & $n 3$ & na & Vis & r.1 & $n 2$ & 183 & (13) & $x t_{4}$ \\
\hline 1 & 200 & 200 & 200 & 100 & 200 & 200 & 10 & 100 & 100 & 200 & 300 & 200 & 30 & 100 & 200 & 200 & 200 & 200 & $7 \pm 0$ & 100 & 200 & 100 & 100 \\
\hline & 200 & 100 & 100 & 200 & 100 & 100 & 200 & 200 & 30 & 200 & 100 & 10 & 200 & 200 & 20 & 200 & 10 & 200 & 200 & 100 & 200 & 20 & 20 \\
\hline 3 & $2 \alpha$ & $2 \alpha$ & 200 & 200 & 200 & 20 & 300 & 200 & 20 & 200 & 30 & 200 & 20 & 20 & 200 & 200 & 300 & 300 & 200 & 200 & 20 & 100 & 20 \\
\hline 4 & 200 & 200 & 200 & 200 & 300 & 200 & 300 & 200 & 20 & 200 & 200 & 200 & 100 & 200 & $t \infty 0$ & 100 & 200 & 1,00 & 200 & 200 & 300 & 300 & 200 \\
\hline 5 & 100 & 100 & 100 & 200 & 100 & 200 & 100 & 200 & 200 & 200 & 100 & 100 & 200 & 100 & 100 & 100 & 200 & 300 & 1.50 & 200 & 200 & 100 & 200 \\
\hline 6 & 200 & 10 & 200 & 200 & 100 & 200 & 200 & 200 & 200 & 300 & 100 & 100 & 200 & 200 & 100 & (1.08 & $1(x)$ & 1,00 & 100 & 100 & 700 & 200 & 200 \\
\hline 7 & 200 & 100 & 100 & 200 & 100 & 200 & 100 & 100 & 200 & 100 & 100 & 100 & 100 & 100 & 1010 & 200 & 200 & 10 & 100 & 200 & 200 & 100 & 10 \\
\hline ค & 200 & 100 & 200 & 200 & 200 & 100 & 100 & 100 & 200 & 200 & 200 & 300 & 200 & 300 & 100 & 100 & 200 & 1.00 & 200 & 100 & 200 & 100 & 100 \\
\hline 9 & 100 & 100 & 200 & 200 & 200 & 100 & 100 & 100 & 100 & 200 & 200 & 300 & 300 & 300 & 100 & 100 & 200 & 200 & 200 & 200 & 200 & 100 & $\infty$ \\
\hline t: & 100 & 10 & 300 & 200 & 200 & 100 & 100 & 500 & 200 & 100 & 190 & 100 & 200 & 200 & $10 \pi$ & 1.08 & 1010 & 1.00 & 2000 & 100 & 10 & 100 & 100 \\
\hline 1 & 200 & 200 & 100 & 200 & 100 & 200 & 200 & 200 & 200 & 200 & 100 & 100 & 200 & 200 & 200 & $2 \pi$ & 200 & 100 & 150 & 200 & 200 & 200 & 200 \\
\hline 1 & 200 & 200 & 300 & 200 & 100 & 200 & 200 & 200 & 200 & 100 & 100 & 100 & 200 & 200 & 100 & 100 & 200 & 1.00 & 2.00 & 200 & 200 & 200 & 200 \\
\hline 17 & 200 & 100 & $z \infty 0$ & 200 & 100 & 200 & 100 & 100 & 200 & 300 & 100 & 100 & 200 & 100 & 100 & 100 & 100 & 100 & 100 & 200 & 200 & 100 & 100 \\
\hline 18 & 300 & 200 & 200 & 200 & 200 & 100 & 100 & 100 & 200 & 200 & 200 & 100 & 200 & 300 & 20 & 300 & 100 & $10 \pi$ & 180 & 300 & 300 & 100 & 70 \\
\hline & & 20 & 200 & 200 & 200 & 200 & 100 & 100 & 200 & 200 & 200 & 200 & 200 & 200 & 300 & 300 & 300 & 200 & 150 & 300 & 200 & 100 & 100 \\
\hline u & & 300 & 200 & 200 & 2000 & -2000 & 700 & 200 & 200 & 200 & 200 & 200 & 100 & 20 & 300 & 200 & $x, 00$ & 200 & 130 & 300 & 300 & 200 & 30 \\
\hline 17 & 200 & 1000 & 300 & 200 & 100 & 200 & 200 & 200 & 200 & 200 & 300 & 300 & 200 & $3 \omega$ & 200 & 200 & 300 & 300 & 120 & 300 & 300 & 200 & 200 \\
\hline $\mathrm{z}$ & 100 & 200 & 300 & 200 & 200 & 200 & 30 & 300 & 100 & 300 & 100 & 100 & 200 & 10 & itin & 3 in & $2 m$ & 20 & 200 & 200 & 300 & 300 & 100 \\
\hline
\end{tabular}

Gambar 4. Tampilan Data Hasil Recode nama Variabel yang disesuaikan [14]

Rata-rata beberapa matakuliah yang sama (Teori dan Praktik) memperkecil jumlah indikator yang keseluruhan sebelumnya berjumlah 21 indikator menjadi 13 indikator dengan variabel eksogen $\mathrm{X} 1$ sebanyak 3 buah indikator, variabel eksogen X2 sebanyak 4 buah indikator, variabel endogen Y1 sebanyak 3 buah indikator, dan variabel endogen sebanyak 3 buah indikator (Gambar 5). 


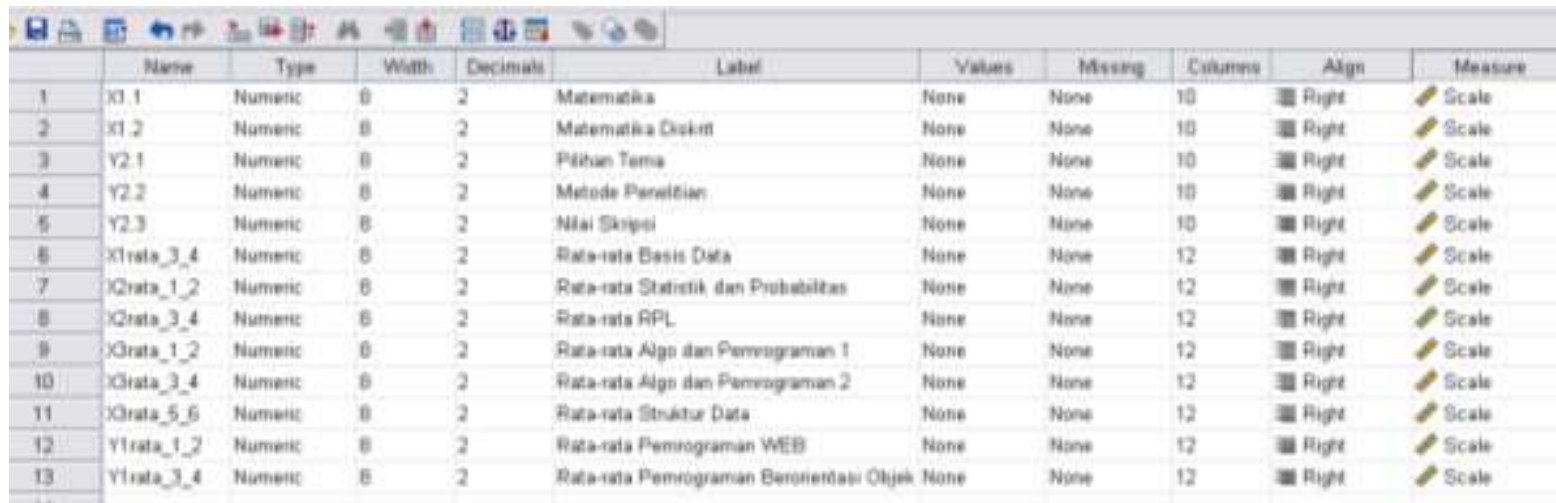

Gambar 5. Tampilan Variabel (Semua Indikator) Setelah Rataan Nilai Teori dan Praktik [14]

Membuat tipe data dari non numerik menjadi numerik agar dapat dihitung dengan aplikasi Lisrel 8.8. Selanjutnya memperlihatkan data tidak ada yang missing value agar layak untuk perhitungan selanjutnya [15].

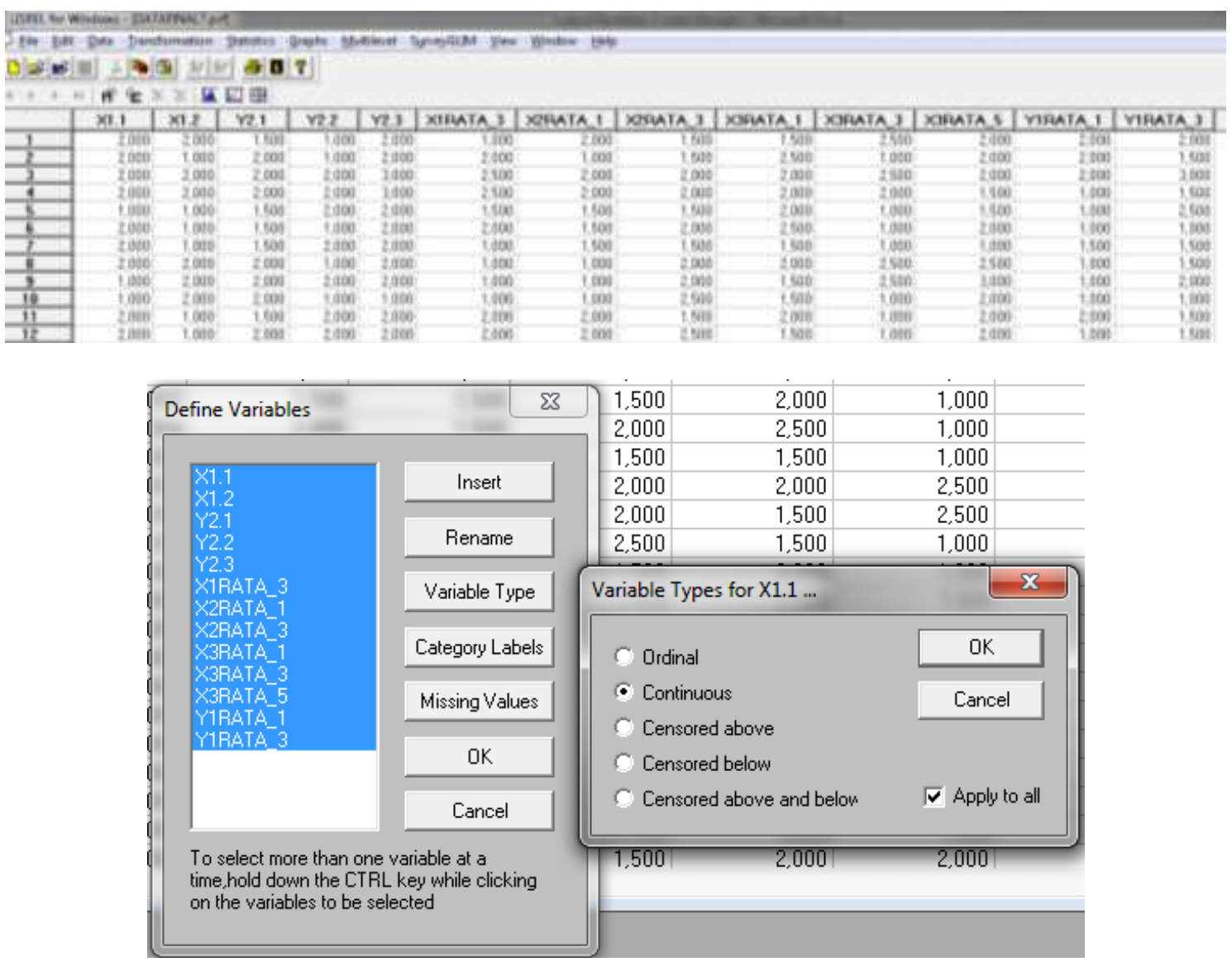

Gambar 6. Konversi Tipe Data String ke Numerik

\subsection{Uji Normalitas Data Penelitian 13 Manifestasi dan 5 Buah Konstruk}

Menu Output aplikasi Lisrel dijalankan dengan pilihan multivariate normality dan nilai covarians yang digunakan selama Running. Pada Gambar 7 dan Gambar 8 memperlihatkan data secara univariate berdistribusi normal jika semua manifes memiliki nilai skewness dan kurtosis pada p-value > 0,05. Ternyata X1.2, Y2.1, Y2.2, X1RATA_1, Y1RATA_1, dan Y1RATA_3 tidak memenuhi kondisi tersebut. Tetapi untuk tes multivariate normality secara keseluruhan variabel dapat dikatakan berdistribusi normal dengan nilai skewness dan kurtosis pada p-value yaitu 0,637>0,05. 


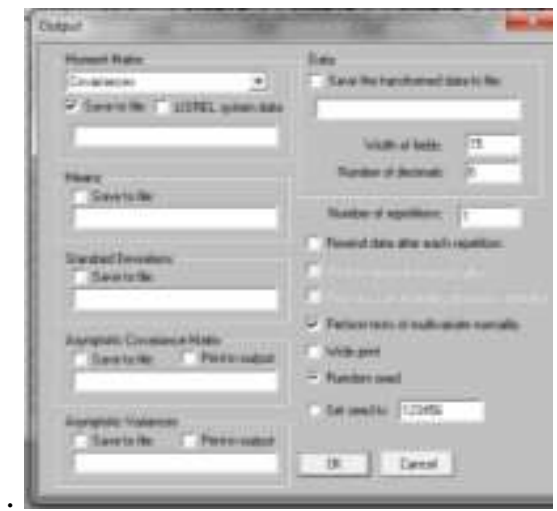

\section{Gambar 7. Jendela Menu Output Pemeriksaan Normalitas}

\begin{tabular}{|c|c|c|c|c|c|c|}
\hline & \multicolumn{2}{|c|}{ Skewness } & \multicolumn{2}{|c|}{ Kurtosis } & Skewness and & d Kurtosis \\
\hline Variable & Z-Score & P-Value & Z-Score & P-Value & Chi-Square & P-Value \\
\hline $\mathrm{X} 1.1$ & -0.557 & 0.578 & -1.586 & 0.113 & 2.824 & 0.244 \\
\hline $\mathrm{X} 1.2$ & 0.735 & 0.462 & -4.271 & 0.000 & 18.785 & 0.000 \\
\hline Y2.1 & 1.628 & 0.103 & 31.252 & 0.000 & 979.324 & 0.000 \\
\hline$Y 2.2$ & 0.128 & 0.898 & 2.711 & 0.007 & 7.366 & 0.025 \\
\hline Y2. 3 & -0.087 & 0.931 & 0.324 & 0.746 & 0.113 & 0.945 \\
\hline X1RATA_3 & 1.427 & 0.154 & -2.642 & 0.008 & 9.016 & 0.011 \\
\hline X2RATA_1 & 0.667 & 0.505 & -1.350 & 0.177 & 2.268 & 0.322 \\
\hline X2RATA_3 & 0.439 & 0.661 & -1.833 & 0.067 & 3.552 & 0.169 \\
\hline X3RATA_1 & -0.462 & 0.644 & -1.993 & 0.046 & 4.184 & 0.123 \\
\hline ATA_3 & 0.243 & 0.808 & -1.240 & 0.215 & 1.597 & 0.450 \\
\hline 5 & 0.073 & 0.942 & -0.432 & 0.666 & 0.192 & 0.909 \\
\hline Y1RATA_- & 0.490 & 0.624 & -3.931 & 0.000 & 15.693 & 0.000 \\
\hline Y1RATA_3 & 0.714 & 0.475 & -3.951 & 0.000 & 16.117 & 0.000 \\
\hline
\end{tabular}

Relative Multivariate Kurtosis $=0.967$

Test of Multivariate Normality for Continuous Variables

\begin{tabular}{|c|c|c|c|c|c|}
\hline & Skewness & & Kurtosis & Skewness and & Kurtosis \\
\hline Value & Z-Score P-Value & Value & Z-Score P-Value & Chi-Square & P-Value \\
\hline 22.136 & $\begin{array}{ll}-0.264 & 0.791\end{array}$ & 188.527 & $-0.912 \quad 0.362$ & 0.901 & 0.637 \\
\hline
\end{tabular}

Gambar 8. Output Nilai Skewess Dan Kurtosis Aplikasi Lisrel

\subsection{Loading Factor Manifestasi dan Konstruk}

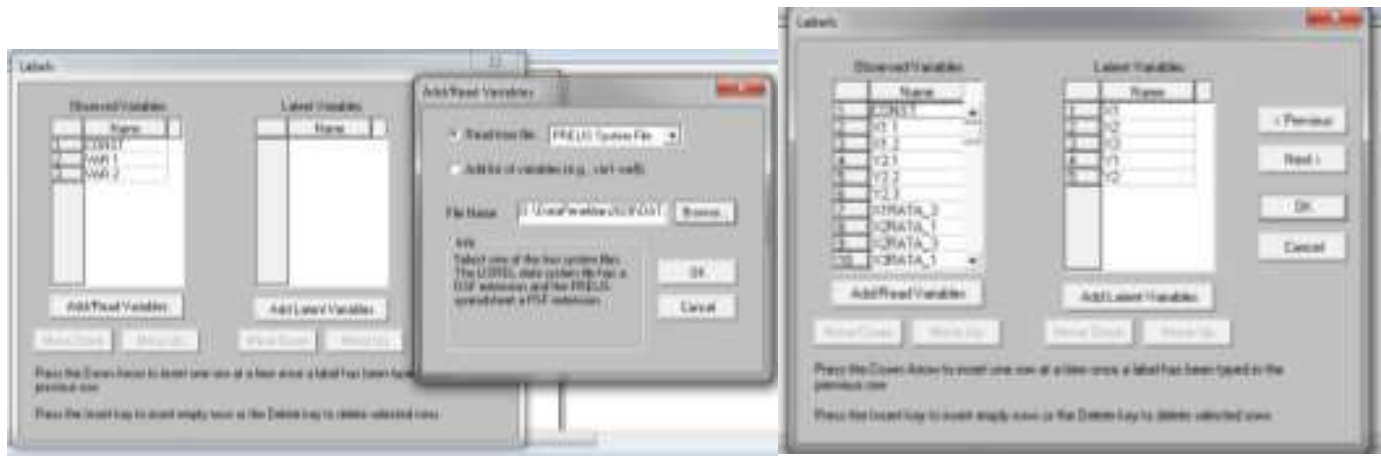

Gambar 9. Set-up Data Dari Variabel Dalam File Prelis

Pada tahapan ini (Gambar 9) dilakukan pengaktifan file prelis untuk menampilkan diagram konsep, nilai estimasi, standard solution, nilai T-value, dan modifikasi yang disarankan. Berikut ini kode dan tampilan luaran dari aplikasi Lisrel pada konstruk X1, X2, dan X3. 


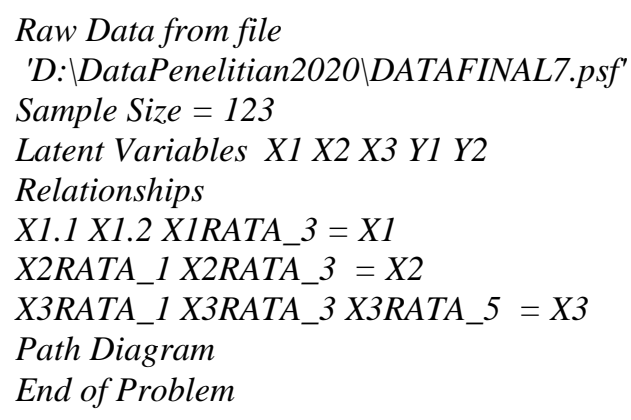

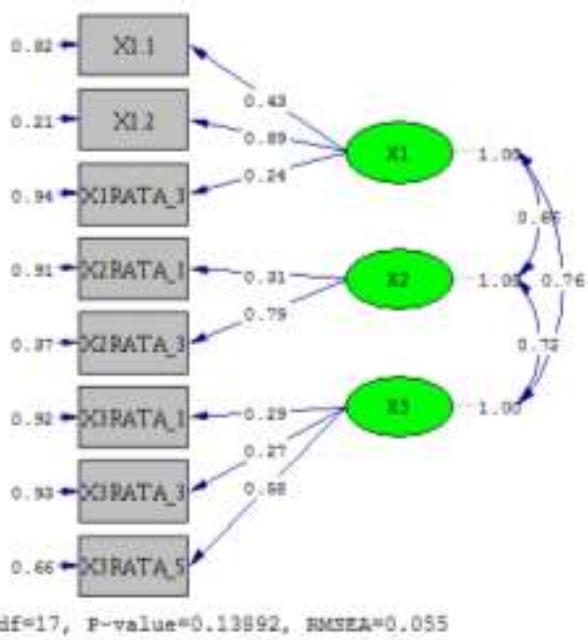

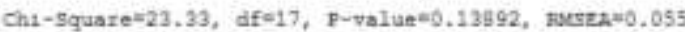

\section{Gambar 10. Tampilan Manifes Model Laten Eksogen untuk Variabel X1, X2, dan X3}

Terlihat pada Gambar 10 diagram model manifes untuk loading factor yang tidak baik nilai signifikannya (lebih kecil dari 0,05 ), kemudian error covariance nya yang terlalu besar (sebelah kiri notasi gambar persegi). Sehingga beberapa variabel perlu di drop atau di hilangkan dari model untuk mendapatkan model yang fit nantinya.

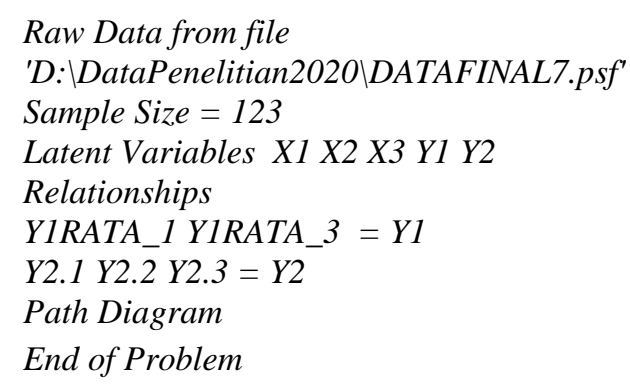

\section{Gambar 11. Tampilan Manifes Model Laten Endogen untuk Variabel Y1, dan Y2}

Kode berikut ini untuk menampilkan diagarm laten endogen bersama manifesnya. Terlihat Gambar 11 pada diagram model manifes untuk variabel endogen dengan nilai loading factor yang tidak baik jika nilai signifikannya karena $<0.05$, kemudian error covariance untuk setiap manifes nilai yang terlalu besar. Untuk itu juga sama dengan manifes eksogen variabelnya perlu di drop atau di hilangkan dari model.

Selanjutnya running (jalankan) kode berikut dengan file prelis .psf untuk menampilkan semua manifes semua konstruk seperti berikut. 
Raw Data from file

'D: DataPenelitian2020WDATAFINAL7.psf'

Sample Size $=123$

Latent Variables X1 X2 X3 Y1 Y2

Relationships

X1.1 X1.2 X1RATA_3 $=X 1$

$X 2 R A T A \_1$ X2RATA_3 $=X 2$

X3RATA 1 X3RATA_3 X3RATA_5 $=X 3$

YIRATA_1 YIRATA_3 $=Y 1$

$Y 2.1 Y 2.2 Y 2.3=Y 2$

Path Diagram

End of Problem

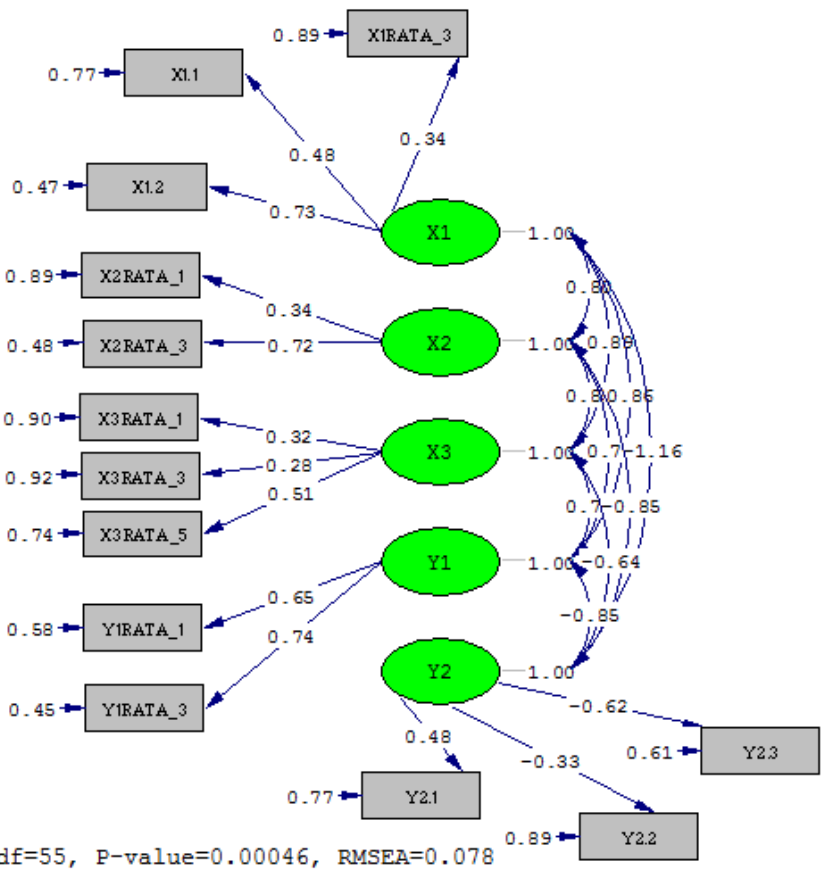

Chi- - quare $=96.48, d f=55, \mathrm{P}-\mathrm{value}=0.00046, \mathrm{RMSEA}=0.078$
Gambar 12. Diagram X-Model untuk Manifes Semua Konstruk

Hasil tampilan diagram model untuk semua manifes masing-masing konstruk dengan nilai loading factor yang lebih kecil dari 0.05 , selain itu terdapat error covariance pada manifes nilai yang terlalu besar (Gambar 12). Sehingga diperlukan beberapa iterasi agar diperoleh nilai P-value yang lebih besar dari 0.05 dan nilai RMSEA yang lebih kecil dari 0.05 , selanjutnya model tersebut dapat dikatakan fit dengan penguatan beberapa nilai goodness of fit dari model.

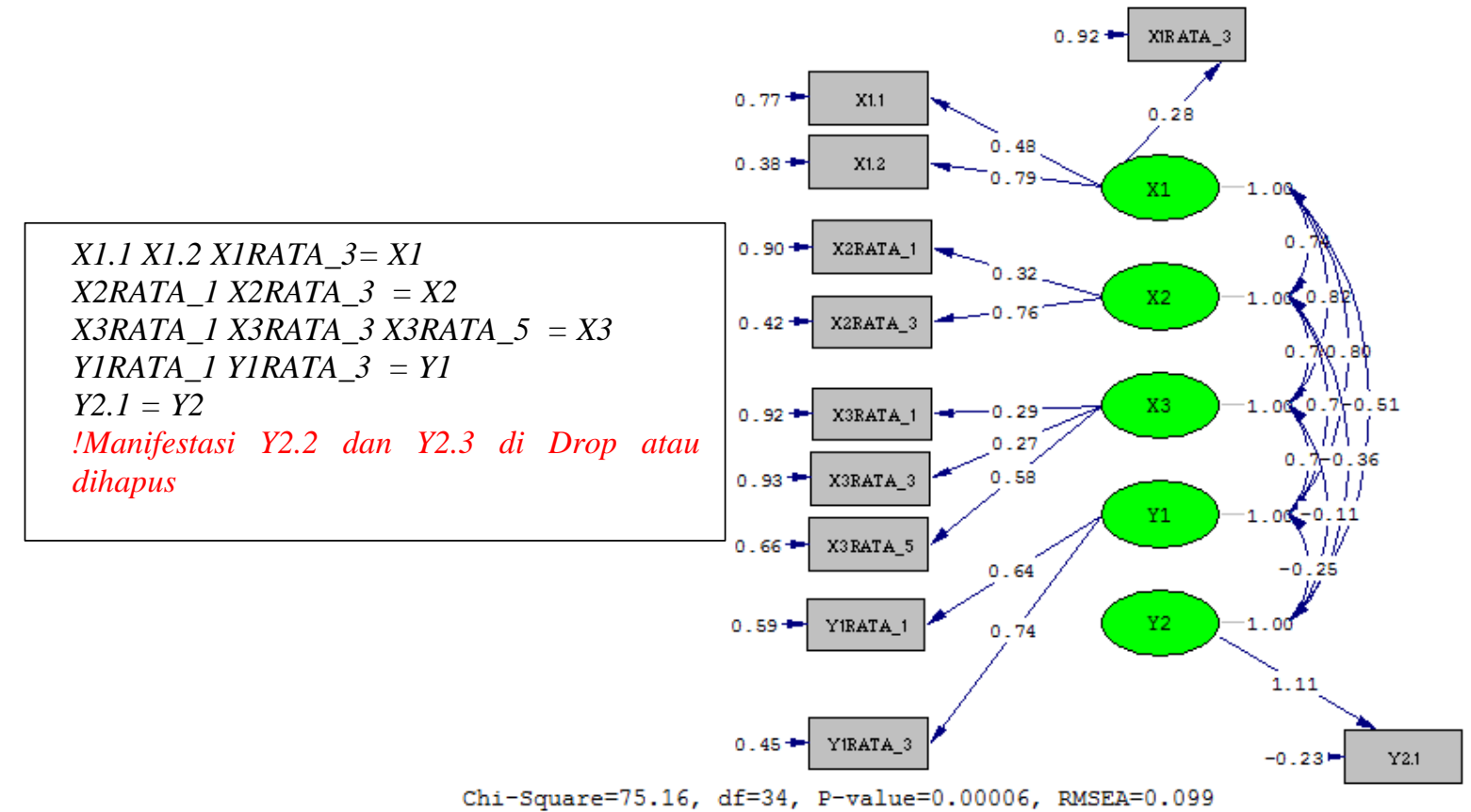

Gambar 13. Tampilan Iterasi Ke 1 Diagram X-Model Manifes Semua Variabel Konstruk

Tampilan iterasi ke 1 untuk diagram X-Model manifes semua variabel konstruk pada Gambar 13 hasil tampilan setelah manifes Y2.2 dan Y2.3 dihilangkan (drop) selanjutnya memperlihatkan adanya perbaikan model Konstruk. Masih ada beberapa nilai loading factor yang perlu dihilangkan dengan melakukan modifikasi model. 
$X 1.1$ X1.2 XIRATA $3=X 1$

X2RATA_1 X2RATA_3 =X2

X3RATA_1 X3RATA_3 X3RATA_5 = X3

YIRATA_1 YIRATA_3 = Y1

$Y 2.1=Y 2$

!Error Covariance Negatif pada manifestasi Y2.1 maka dikali 0.01

Set Error Variance of Y2.1 to 0.01
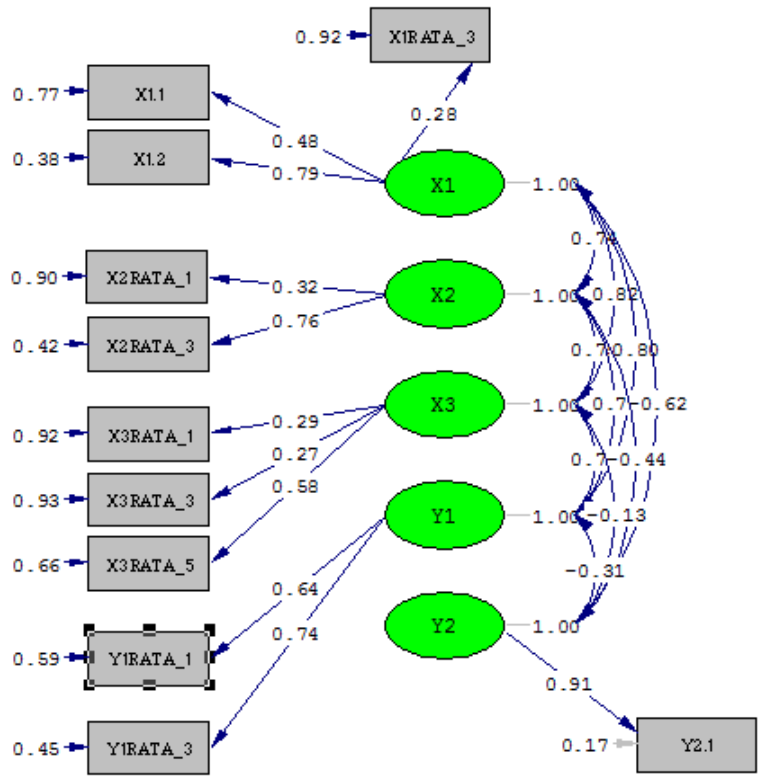

Chi-Square=75.16, df=35, P-value=0.00009, RMSEA=0.097

\section{Gambar 14. Tampilan Iterasi Ke 2 Diagram X-Model Manifes Semua Variabel Konstruk}

Pada Gambar 14 memperlihatkan hasil iterasi ke 2 untuk diagram X-Model bagi manifest yang semua variabel konstruknya setelah Error Covariance yang bernilai negatif pada manifestasi Y2.1 maka dikali 0.01, selanjutnya melakukan Set Error Variance bagi manifes Y2.1 dikali dengan 0.01.

Iterasi ke 3 pada Gambar 15 memperlihatkan hasil diagram X-Model bagi manifest semua variabel konstruknya setelah manifes X1RATA_3 dihilangkan (drop), selanjutnya ada perubahan nilai p-value menjadi 0.00303 yang menaik mendekati nilai 0.05 .

$X 1.1 X 1.2=X 1$

!Manifestasi X1RATA_3 di DROP/ dibuang

X2RATA_1 X2RATA_3 = X2

X3RATA_1 X3RATA_3 X3RATA_5 = X3

YIRATA_1 YIRATA_3 = Y1

$Y 2.1=Y 2$

Set Error Variance of Y2.1 to 0.01

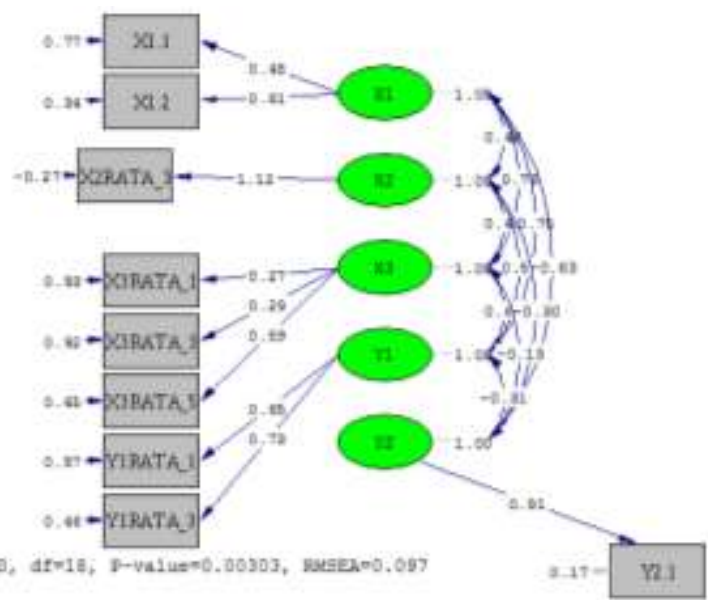

Gambar 15. Tampilan Iterasi Ke 3 Diagram X-Model Manifes Semua Variabel Konstruk

Selanjutnya iterasi yang ke 4 dilakukan dengan cara menghilangkan (drop) variabel manifes X2RATA_1 karena nilainya lebih kecil dari error covariance nya dan diperoleh hasil sebagai berikut (Gambar 16). Terlihat juga perubahan nilai p-value menjadi 0.0084, dan nilai RMSEA menjadi 0.000 . 


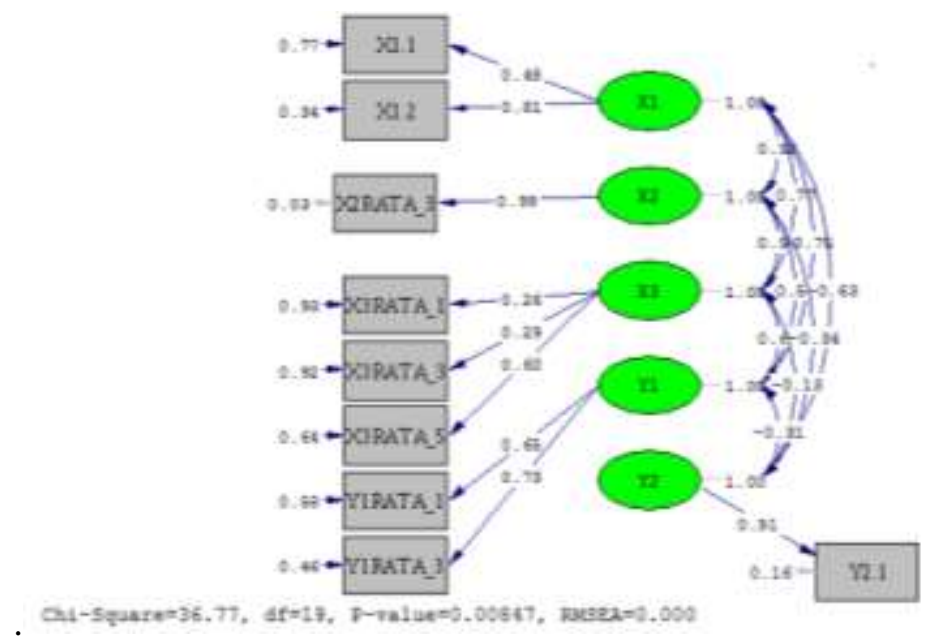

Gambar 16. Tampilan Iterasi Ke 4 Diagram X-Model Manifes Semua Variabel Konstruk

Pada iterasi yang ke 5 juga dilakukan dengan cara menghilangkan (drop) variabel manifes X1.1 karena nilainya loading factor nya lebih kecil dari 0.05 , nilai error covariance-nya masih di atas $50 \%$ dan diperoleh hasil sebagai berikut (Gambar 17). Terlihat juga perubahan nilai p-value menjadi 0.0084, dan nilai RMSEA menjadi 0.000 .

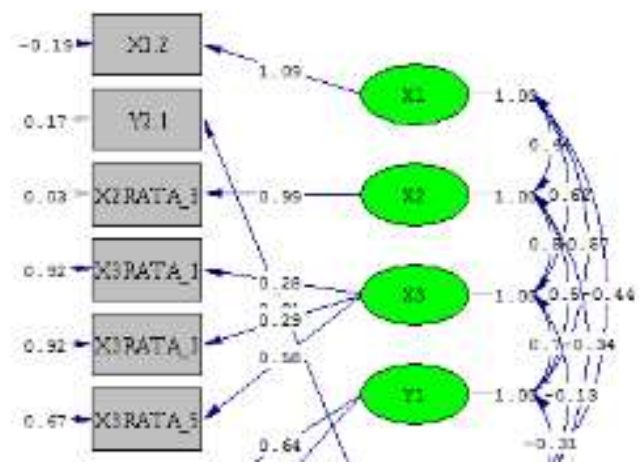

\section{Gambar 17. Tampilan Iterasi Ke 5 Diagram X-Model Manifes Semua Variabel Konstruk}

Pada Gambar 18 untuk iterasi ke 6 diperoleh setelah dilakukan set error variance pada variabel manifes X1.2 dikali dengan nilai 0.01 karena nilai error variance nya bernilai negatif. Selanjutnya diperoleh perubahan nilai p-value menjadi 0.01028 dan nilai RMSEA manjadi 0.00 .

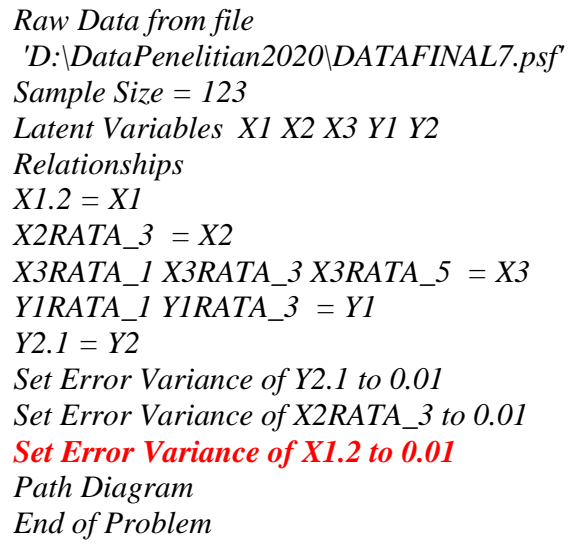

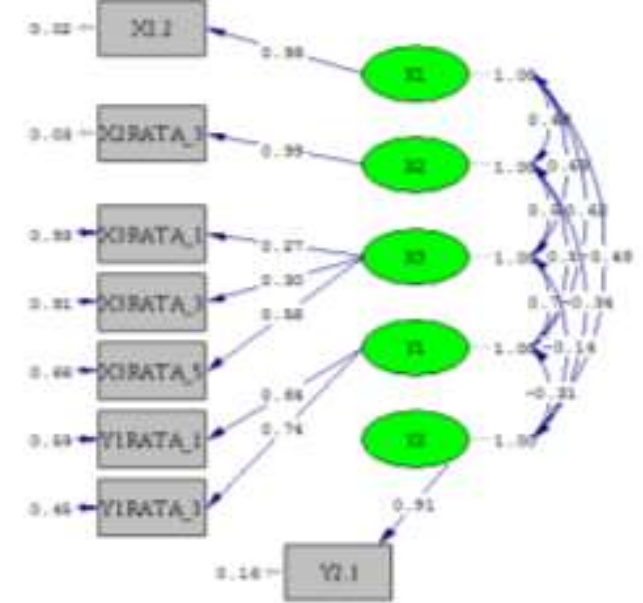

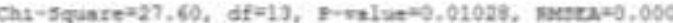

Gambar 18. Tampilan Iterasi Ke 6 Untuk Diagram X-Model Manifes Semua Variabel Konstruk 
Pada Gambar 19 sebagai hasil running setelah iterasi ke 7 dilakukan yaitu dengan cara menghilangkan (drop) untuk variabel manifestasi X3RATA_1. Diperoleh nilai p-value yang masih memenuhi lebih besar dari 0.05 , tetapi nilai RMSEA menjadi tidak memenuhi (seharusnya $<0.05$ ).

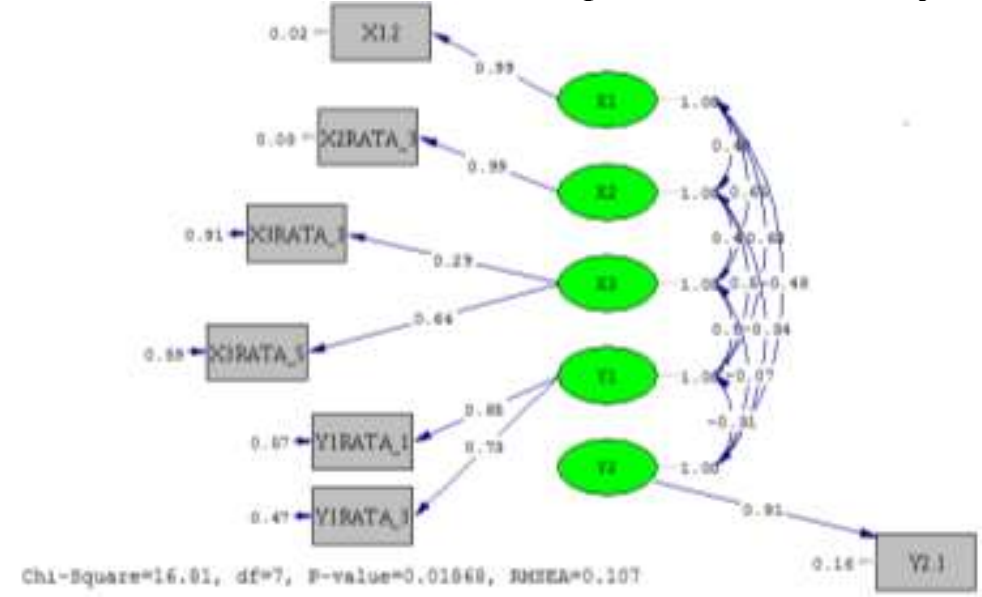

Gambar 19. Tampilan Iterasi Ke 7 Diagram X-Model Manifes Semua Variabel Konstruk
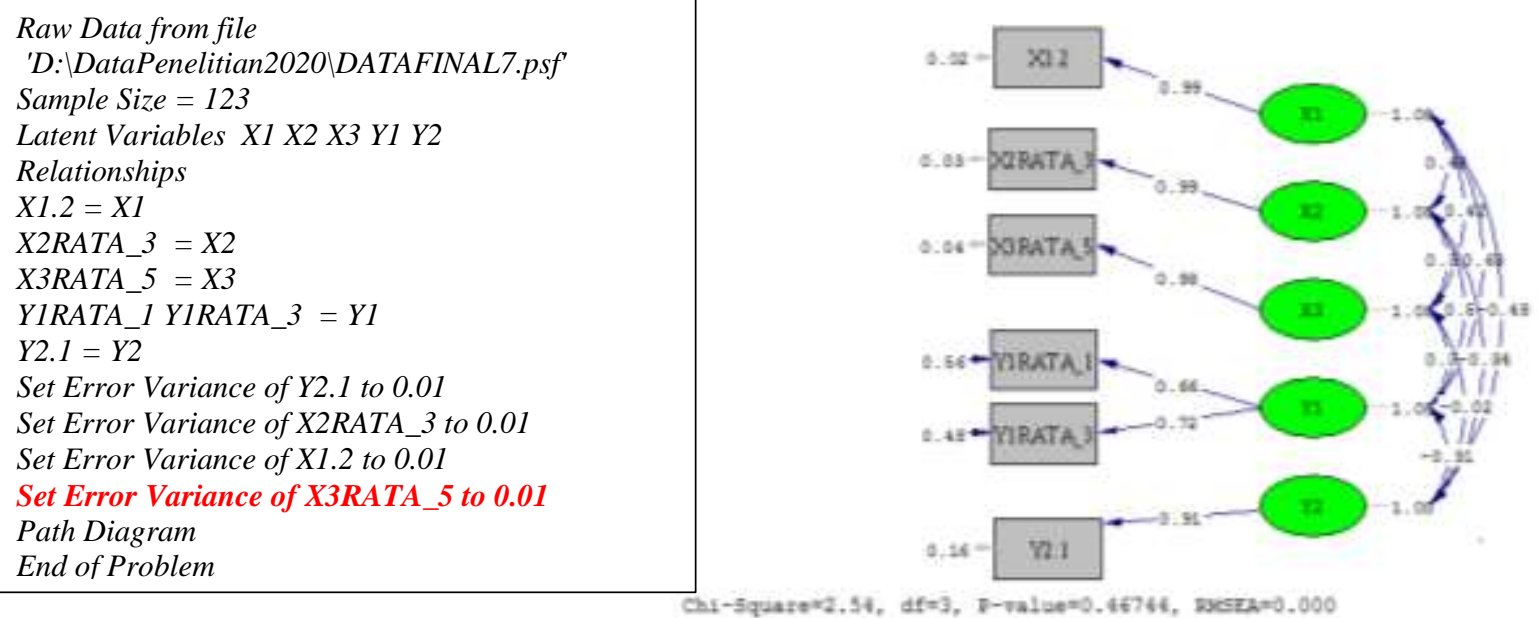

\section{Gambar 20. Tampilan Iterasi Ke 8 Diagram X-Model Manifes Semua Variabel Konstruk}

Iterasi ke 8 memberikan hasil (Gambar 20) dengan cara melakukan Set Error Variance pada variabel manifes X3RATA_5 dikali nilai 0.01. Hal tersebut dilakukan karena nilai error nya yang terlalu besar mempengaruhi nilai p-value dan nilai RMSEA. Setelah running diperoleh perubahan nilai p-value menjadi 0.46744 dan nilai RMSEA sebesar 0.000 .

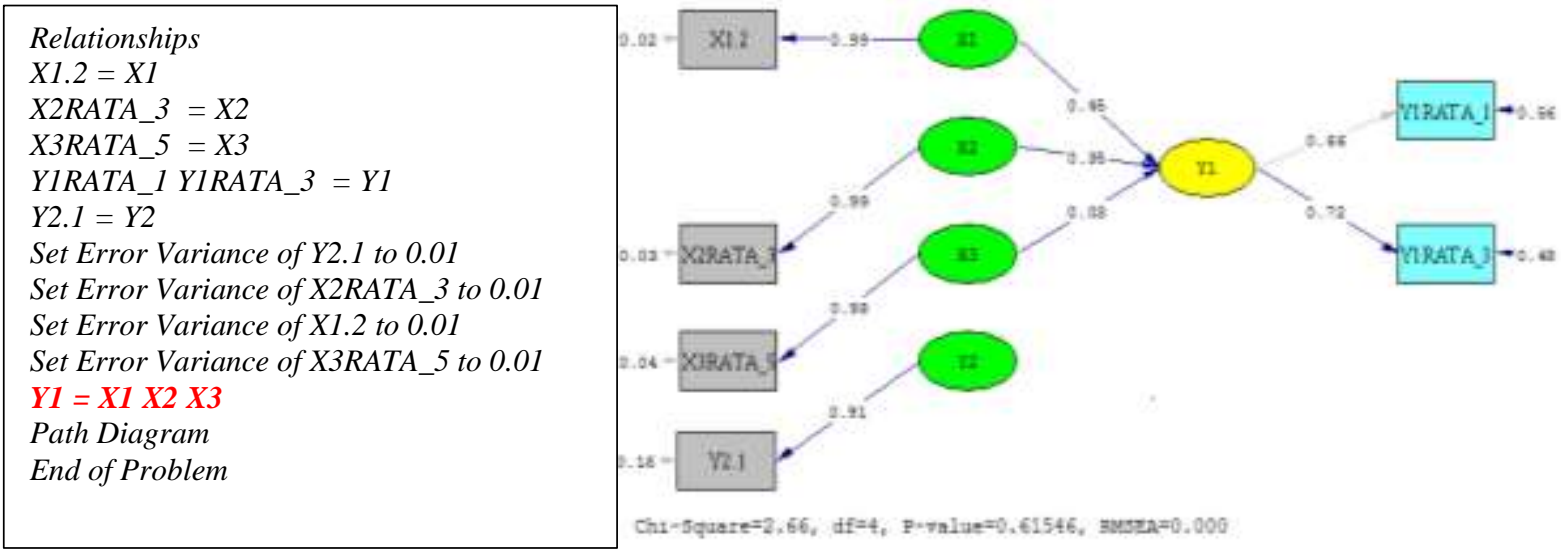

Gambar 21. Tampilan Akhir Untuk Estimasi Laten Y1 Oleh X1, X2, dan X3

Setelah nilai p-value dan RMSEA memenuhi dan model juga memberikan loading factor dengan nilai yang baik yaitu di atas nilai 0.05 atau lebih besar dari nilai error variance nya, tampilan pada 
Gambar 21 memperlihatkan bahwa semua nilai memenuhi kriteria CFA. Selain itu juga, terlihat tampilan notasi relasi hubungan laten $\mathrm{Y} 1$ dengan X1, X2, dan X3 sesudah dilakukan running kode Lisrel.
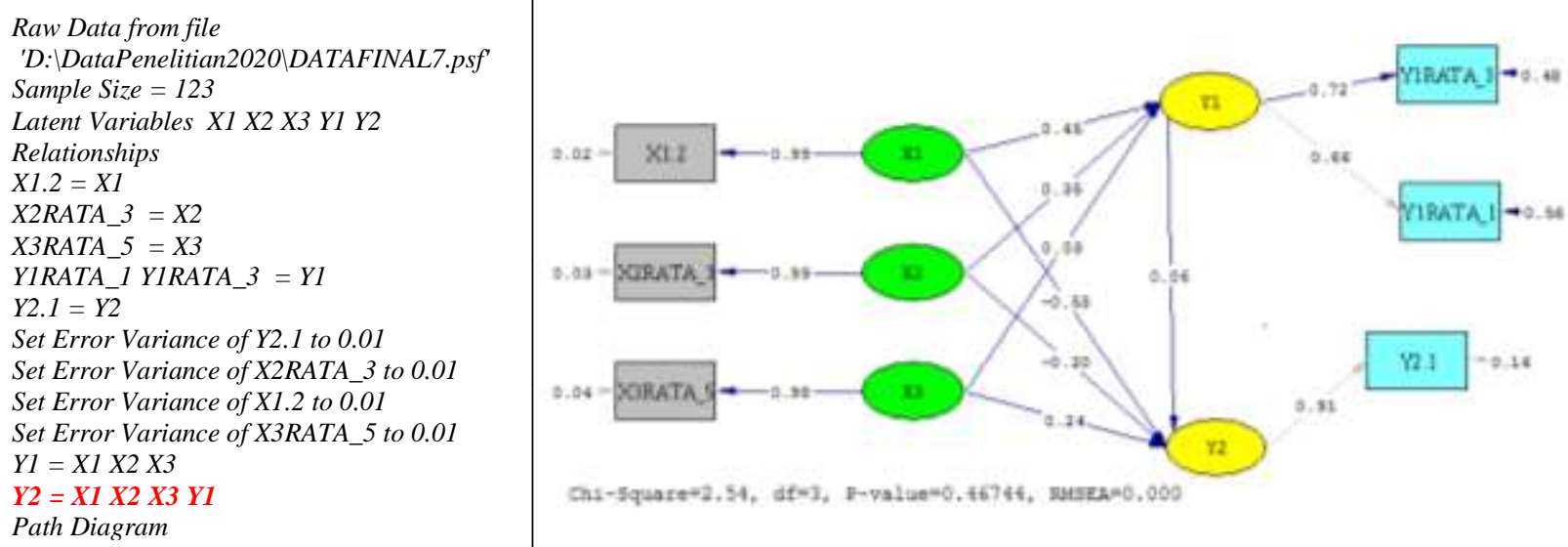

\section{Gambar 22. Tampilan Akhir Untuk Estimasi Y2 Oleh Y1, X1, X2, dan X3}

Gambar 22 yang mengadopsi model pada Gambar 1 tidak ada variabel eksogen dan endogen yang dihapus maupun terdapat relasi yang baru bagi model setelah dilakukan running kode Lisrel dengan melakukan relasi seperti Gambar 1 diperoleh nilai Fit model yang memenuhi persyaratannya (Tabel 4). Terlihat busur atau jalur yang menandakan ada hubungan langsung dan hubungan tidak langsung antar konstruk yang akan dilakukan pengujian.

\subsection{Pengujian Model Struktural Fit}

Untuk memperlihatkan sejauh mana kriteria model termasuk Goodness Of Fit maka diperlihatkan output yang sudah dihasilkan dari running proses model yang terakhir pada rangkuman Tabel 4

Tabel 4. Pengujian Model Penelitian Fit

\begin{tabular}{|l|c|c|c|}
\hline \multicolumn{1}{|c|}{ Goodness Of Fit Index } & Cut-off Value & Hasil & Kesimpulan \\
\hline Chi-square & & 2,54 & \\
\hline Sig. Probability & $>=0,05$ & 0,467 & FIT \\
\hline Deegre of Freedom & $>=0.0$ & 3 & FIT \\
\hline GFI & $>=0,90$ & 0,99 & FIT \\
\hline AGFI & $>=0,90$ & 0,95 & FIT \\
\hline CFI & $>=0,90$ & 1,00 & FIT \\
\hline TLI/ NNFI & $>=0,90$ & 1,01 & FIT \\
\hline IFI & $>=0,90$ & 1,00 & FIT \\
\hline RMSEA & $<=0,08$ & 0,0000 & FIT \\
\hline RMR & $<=0,05$ & 0,0072 & FIT \\
\hline
\end{tabular}

\subsection{Analisa Persamaan Struktural}

Measurement Equations Untuk Setiap Variabel.

a. $Y 2.1=0.23 * Y 2$, Errorvar. $=0.0100, R^{2}=0.84$;

Sebesar 84\% konstruk Y2 mampu menjelaskan manifes atau indikator Y2.1.

b. Y1RATA_1 $=0.44 * Y 1$, Errorvar. $=0.25, R^{2}=0.44$

$$
(0.047) / 5.47
$$

- Sebesar 44\% konstruk Y1 mampu menjelaskan manifes atau indikator Y1RATA_1.

c. Y1RATA_3 $=0.50 * Y 1$, Errorvar. $=0.23, R^{2}=0.52$

$$
(0.097) / 5.21 \quad(0.052) / 4.44
$$

- Sebesar 52\% konstruk Y1 mampu menjelaskan manifes atau indikator Y1RATA_3.

d. $\mathrm{X} 1.2=0.70 * \mathrm{X} 1$, Errorvar $=0.0100, \mathrm{R}^{2}=0.98$

$$
(0.046) / 15.31
$$


- Sebesar 98\% konstruk X1 mampu menjelaskan manifes atau indikator X1.2.

e. X2RATA_3 $=0.58 * X 2$, Errorvar. $=0.0100, R^{2}=0.97$

$(0.038) / 15.16$

- Sebesar 97\% konstruk X2 mampu menjelaskan manifes atau indikator X2RATA_3.

f. X3RATA_5 $=0.50 * X 3$, Errorvar. $=0.0100, R^{2}=0.96$

$(0.033) / 15.02$

- Sebesar 96\% konstruk X3 mampu menjelaskan manifes atau indikator X3RATA_5.

Nilai t-statistik untuk manifes Y1RATA_1, Y1RATA_3, X1.2,X2RATA_3, X3RATA_5 masing-masing manifes yaitu 5.47, 5.21, 15.31, 15.16, 15.02 .

Persamaan Struktural:

$$
\begin{aligned}
& \mathrm{Y} 1=0.45 * \mathrm{X} 1+0.35 * \mathrm{X} 2+0.027 * \mathrm{X} 3, \text { Errorvar. }=0.50, \mathrm{R}^{2}=0.50 \\
& \begin{array}{llll}
(0.13) & (0.12) & (0.11) & (0.18)
\end{array} \\
& \begin{array}{llll}
3.52 & 2.98 & 0.26 & 2.79
\end{array} \\
& \mathrm{Y} 2=0.061 * \mathrm{Y} 1-0.53 * \mathrm{X} 1-0.20 * \mathrm{X} 2+0.24 * \mathrm{X} 3, \text { Errorvar. }=0.70, \mathrm{R}^{2}=0.30 \\
& \begin{array}{lllll}
(0.18) & (0.14) & (0.12) & (0.100) & (0.12)
\end{array} \\
& \begin{array}{lllll}
0.35 & -3.86 & -1.64 & 2.44 & 6.02
\end{array}
\end{aligned}
$$

\section{Persamaan Struktural Lainnya:}

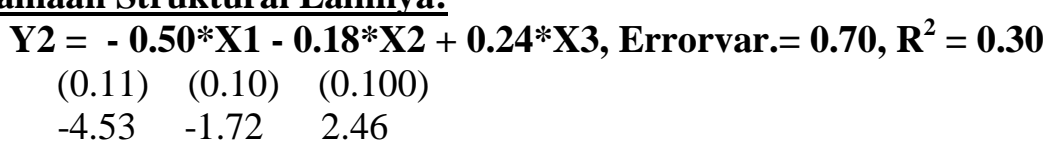

\subsection{Pengujian Hipotesa}

Pengujian Hipotesis 1: Hipotesis ini menguji hubungan langsung antara variabel X1 dengan variabel Y1. Karena nilai t-value sebesar 3,52>=1,967 maka H0 ditolak, yang artinya bahwa ada pengaruh antara variabel $\mathrm{X} 1$ terhadap $\mathrm{Y} 1$

Pengujian Hipotesis 2: Hipotesis ini menguji hubungan langsung antara variabel X2 dengan variabel Y1. Karena nilai t-value sebesar 2,98>=1,967 maka H0 ditolak, yang artinya bahwa ada pengaruh antara variabel $\mathrm{X} 2$ terhadap $\mathrm{Y} 1$

Pengujian Hipotesis 3: Hipotesis ini menguji hubungan langsung antara variabel X3 dengan variabel Y1. Karena nilai t-value sebesar $0,26<=1,967$ maka H0 diterima, yang artinya bahwa tidak ada pengaruh antara variabel X3 terhadap Y1

Pengujian Hipotesis 4: Hipotesis ini menguji hubungan langsung antara variabel X1 dengan variabel Y2. Karena nilai t-value sebesar $-4,53<=1,967$ maka H0 diterima, yang artinya bahwa tidak ada pengaruh antara variabel $\mathrm{X} 1$ terhadap $\mathrm{Y} 2$

Pengujian Hipotesis 5: Hipotesis ini menguji hubungan langsung antar variabel X2 dengan variabel Y2. Karena nilai t-value sebesar $-1,72<=1,967$ maka H0 diterima, yang artinya bahwa tidak ada pengaruh antara variabel $\mathrm{X} 2$ terhadap $\mathrm{Y} 2$

Pengujian Hipotesis 6: Hipotesis ini menguji hubungan langsung antar variabel X3 dengan variabel Y2. Karena nilai t-value sebesar 2,46>=1,967 maka H0 ditolak, yang artinya bahwa ada pengaruh antara variabel $\mathrm{X} 3$ terhadap $\mathrm{Y} 2$

Pengujian Hipotesis 7: Hipotesis ini menguji hubungan langsung antar variabel Y1 dengan variabel Y2. Karena nilai t-value sebesar $0,35<=1,967$ maka $\mathrm{H} 0$ diterima, yang artinya bahwa tidak ada pengaruh langsung antara variabel Y1 terhadap Y2

Akan tetapi hubungan tidak langsung memberikan hasil:

Pengujian Hipotesis 7: Hipotesis ini menguji hubungan tidak langsung antar variabel $\mathrm{X} 1, \mathrm{X} 2, \mathrm{X} 3$, dan Y1 dengan variabel Y2.

H0: Tidak terdapat pengaruh X1, X2, X3, Y1 terhadap Y2

$\mathrm{H} 1$ : Terdapat pengaruh $\mathrm{X} 1, \mathrm{X} 2, \mathrm{X} 3, \mathrm{Y} 1$ terhadap Y2

Berdasarkan hasil Uji Goodness Of Fit Full Model yang terakhir mengindikasikan bahwa full model SEM dengan $\mathrm{p}=0,467>=0,05$, sehingga dapat disimpulkan $\mathrm{H} 0$ ditolak, artinya Terdapat pengaruh positif dan signifikan $\mathrm{X} 1, \mathrm{X} 2, \mathrm{X} 3, \mathrm{Y} 1$ secara bersama-sama terhadap Y2 hanya sebesar $30 \%$. 


\section{Kesimpulan}

Hasil analisis yang telah dilakukan pada penelitian ini memberikan beberapa kesimpulan yaitu kemampuan mahasiswa dalam membuat kode program ternyata secara langsung tidak dipengaruhi oleh kemampuan algoritma dan pemrograman, maupun kemampuan numerik dan logika yang dimiliki mahasiwa, tetapi hanya dipengaruhi oleh kemampuan analisis data. Mahasiswa dalam memilih tema skripsi secara langsung tidak dipengaruhi kemampuan numerik dan logika, maupun kemampuan analisis data, tetapi hanya dipengaruhi oleh kemampuan algoritma dan pemrograman yang dimiliki mahasiswa. Kemampuan mahasiswa dalam membuat kode program secara bersama-sama ternyata dipengaruhi secara kuat positif (sebesar 50\%) oleh kemampuan numerik dan logika, analisis data, algoritma dan pemrograman. Perlu mendapat perhatian penuh karena ternyata mahasiswa dalam memilih tema skripsi secara bersama-sama mendapat pengaruh yang lemah positif (hanya sebesar 30 $\%$ ) dari kemampuan numerik dan logika, analisis data, algoritma dan pemrograman, juga kemampuan membuat program.

\section{Referensi}

[1] V. Panggayuh, "Pengaruh Kemampuan Metakognitif Terhadap Prestasi Akademik Mahasiswa Pada Mata Kuliah Pemrograman Dasar," Jipi, Vol. 02, Hal. 20-25, 2017.

[2] B. H. A. Pratama and B. Sujatmiko, "Analisis Pengaruh Nilai Tes Potensi Akademik Pada Evaluasi Pemrograman Dasar Terhadap Motivasi dan Kemampuan Pemrograman," It-Edu, Vol. 03 No 01, pp.218-226, 2018, [Daring]. Tersedia pada:

https://Jurnalmahasiswa.Unesa.Ac.Id/Index.Php/It-Edu/Article/View/26431/24205.

[3] R. F. Suwarman, "Analisis Tingkat Kemampuan Pemahaman Konsep Mahasiswa Pada Mata Kuliah Pemrograman Komputer," Prisma, Vol. 7, No. 2, Hal. 227, 2018, Doi: $10.35194 / \mathrm{Jp} . \mathrm{V} 7 \mathrm{i} 2.529$.

[4] F. N. Hasanah dan R. S. Untari, "Analisis Kemampuan Mendeteksi Eror Kode Program Mata Kuliah Pemrograman Berorientasi Objek Pada Program Studi Pendidikan Teknologi Informasi Universitas Muhammadiyah Sidoarjo," J. Teknol. Dan Kejuru., Vol. 41, No. 2, Hal. 139-146, 2018, Doi: 10.17977/Um031v41i22018p139.

[5] I. Mardiyati, "Tingkat Kemampuan Analisa Dan Sintesa Mahasiswa Jurusan Pendidikan Guru Raudhatul Athfal Ftik Iain Pontianak Ta. 2016/2017," Khatulistiwa, Vol. 07 No. 2, 2017, Doi: 10.24260/Khatulistiwa.V7i2.952.

[6] Bidang KKNI, "Kerangka Kualifikasi Nasional Indonesia (KKNI) Rumpun Ilmu Informatika dan Komputer," In Naskah, T. B. KKNI, Ed. Aptikom, 2015, Hal. 1-186.

[7] F. Indrawati, "Pengaruh Kemampuan Numerik Dan Cara Belajar Terhadap Prestasi Belajar Matematika," Form. J. Ilm. Pendidik. MIPA, Vol. 3, No. 3, Hal. 215-223, 2015, Doi: 10.30998/Formatif.V3i3.126.

[8] Pressman, R.S., "Rekayasa Perangkat Lunak: Pendekatan Praktisi Buku I," In 1, Yogyakarta: Andi, 2015.

[9] A. Syamsudin, "Analisis Kesalahan Coding Pemrograman Java Pada Matakuliah Algoritma Pemrograman Mahasiswa Tadris Matematika Iain Kediri," Focus Action Res. Math., Vol. 2, Number, Hal. 102-114, Doi: 10.30762/F.

[10] N. Pohan, Pelaksanaan Proses Belajar Melalui Bimbingan Aspek Afektif, Kognitif Dan Psikomotorik Siswa Di Madrasah Ibtidaiyah Swasta Amal Shaleh Medan. 2017.

[11] P. Ghozali Imam, Structural Equation Modeling Teori, Konsep, Dan Aplikasi Dengan Program Lisrel 9.10. Semarang: Undip, 2014.

[12] P. Haryono, S., Metode Sem Untuk Penelitian Manajemen Amos, Lisrel, Pls. Luxima Metro Media, 2017.

[13] Akmam dan H. Amir, "Pengaruh Pembelajaran Generatif Berbasis Strategi Konflik Kognitif Terhadap Kompetensi Mahasiswa dalam Mata Kuliah Algoritma dan Pemograman Komputer," In Semirata, Vol. Buku 2, Jambi: Wilayah Barat, 2017, Hal. 1285-1294.

[14] Singgih Santoso, Menguasai SPSS Versi 25. Elex Media Komputindo, 2019.

[15] R. F. Suwarman Et Al., "Analisis Tingkat Kemampuan Pemahaman Konsep," vol. VII, no. 2, hal. 227-237, 2018. 